\title{
Implementation of Corporate Social Responsibility (CSR) of Cement Factory: Partnership Program, Environmental Guidance, and National Company-Care
}

\author{
Zainal A.Haris", Asdi Agustar ${ }^{*}$, Melinda Noer ${ }^{*}$, and Yulnafatmawita* \\ \# University Putra Indonesia-YPTK, Lubuk Begalung, Padang, Indonesia \\ E-mail: zainal_aharis@yahoo.com \\ * Faculty of Agricultural Technology Andalas University, West Sumatera, 25163, Indonesia \\ E-mail:asdiagustar@yahoo.com; melindanoer@yahoo.com; yulna_fatmawita@yahoo.com;
}

\begin{abstract}
Corporate Social Responsibility (CSR) of a company is aimed to improve social welfare around the company, then to get good relationship among people in the society as well as between society and the company itself for the sustainability. A research about implementation of Corporate Social Responsibility (CSR) program of PT. Semen Padang, a cement factory, was aimed to identify programs and collaborative model conducted by PT. Semen Padang in implementing the CSR program. This research was conducted in Batu Gadang Lubuk Kilangan (which is categorized as ring I for CSR receiver) located next to limestone hill, a source of raw material for cement Padang. Data were collected by interviewing CSR Bureau of PT Semen Padang, local government ("Kelurahan") staffs, local organization ("KAN") staffs, people in Batu Gadang receiving and non-receiving CSR using survey method. Data were analyzed using Descriptive Analyses method. Based on the data collected, it could be concluded that PT Semen Padang totally had allocated fund for the CSR more than the amount $(>2 \%)$ it had to set aside. The CSR program was implemented through 3 forms, those were Partnership Program (PP), Environmental Guidance (EG) and National Company-Care (NCC), as well as other program which was not included in PP and EG (non-PPEG). Among the programs implemented, partnership program gave better result. If PT Semen Padang fully engaged local organization such as "KAN" as a co-worker, implementation of the CSR program can be more effective and reliable.
\end{abstract}

Keywords - CSR; Corporate Social Responsibility; local organization; Partnership Program; Environmental Guidance; National Company-Care

\section{INTRODUCTION}

Even though corporate social responsibility (CSR) has been discussed for a long time, but it is relatively new in Indonesia. The importance of CSR is supported by Indonesian Government through its regulations [1], which suggest all of the National Corporate Bodies ("BUMN") to set the profit aside to improve the society welfare around the firms known as "Partnership Program and Environmental Guidance (PPEG). Then, the regulation is explained in "BUMN" Ministry's letter [2], and then become rules of the "BUMN" ministry itself, which explained the implementation of the ministry's decision above. Finally, Indonesian government put it into amendment [3]. It is about the responsibility of a company, especially the one which explores natural resources, to implement CSR.

In fact, the CSR concept is meant and therefore implemented different by every company, because it is relatively new for the companies in Indonesia. The CSR is sometimes conducted as a charity program, such as a company contributes some gifts to the people around the company. Actually, the concept of CSR is not the same as charity or philanthropy which are used to have a short term effect rather than long term infestation for the society. The CSR is specifically to empowerment the society, either in terms of economy, social, and culture, therefore, the company can develop sustainability.

One form of the CSR implementation is community development (CD). This program is hopefully able to give opportunity for the target society to actively participate either in planning, conducting, monitoring, or in evaluating the program. In order to be seriously implemented, the CD program should empower and incorporate the social capital available in the surrounding. As stated in a journal [4] that use of social capital in implementing CSR gave good impact either in economy, social, or culture in sustainable way. 
Social capital plays an important role in functionalizing and empowering life of modern society [5]. It is needed in all aspects of human development, such in economy, social, politic, as well as in democratic stabilization. Any problems and deviation happened in several countries are mainly due to stagnation of the social capital. In a journal [6] stated that weakness of the social capital in a society negatively impacted on social welfare. Then, on a research [7] reported that utilization of social capital of local society was able to solve some problems, to improve family income in the society. Furthermore, it was explained the report [7] that social capital will be meaningful if it is combined with modal financial, such as derived from CSR.

PT Semen Padang as a big company processing cement in West Sumatra has payed some of the profit for the development of the surrounding society through its CSR program. The CSR was implemented in several programs. By those, PT Semen Padang in 2011 got award as "The Most Committed Company in Participating All Categories for Indonesian CSR Awards". In this article it is uncovered the method of PT Semen Padang in implementing the CSR, especially in Batu Gadang, the first ring area of PT Semen Padang.

\section{Methodology}

This research was conducted in Batu Gadang, Lubuk Kilangan District, Padang city-West Sumatra, INDONESIA. The area is located in the first ring as priority region for CSR implementation by PT Semen Padang. Research method employed for this study was in form of combination between qualitative and quantitative approach. Combination model used was Dominant-less dominant design [8] with triangulation technique.

Data collected were in form of primary and secondary data. Primary data came from the key informant determined before, either from people in Batu Gadang or from persons in charge for CSR PT Semen Padang. Secondary data, in addition, was got from government and any bodies around and linked to the Batu Gadang, such as data from the local government, local non-government organization (especially "KAN"), and the public schools.

Data collected were analysed using qualitative approach and conducted simultaneously with data collecting (on going analyses) called as triangulation technique. This technique could help data analyses, because this technique was done to gain better meaning about problems being analyzed. Data collected from quantitative approach were analyzed using descriptive statistics like means, percentage, and graphs.

\section{RESULT AND DISCUSSION}

\section{A. Implementation of CSR Program}

Implementation of CSR in PT Semen Padang followed the mission which is going to be "The best and environmental safe of Cement Industry", besides CSR itself was also governed in Ministry law. In operation, CSR PT Semen Padang has had its own CSR organization (Fig. 1).

Procedure used to conduct any of the CSR forms was coordinated by the CSR Bureau responsible to Director. The Bureau was divided into (1) Division of environmental guidance (EG) program and National Company Care (NCC) program, (2) Division of partnership Program (PP), and (3) Division of other than EG and PP (Non-PPEG).

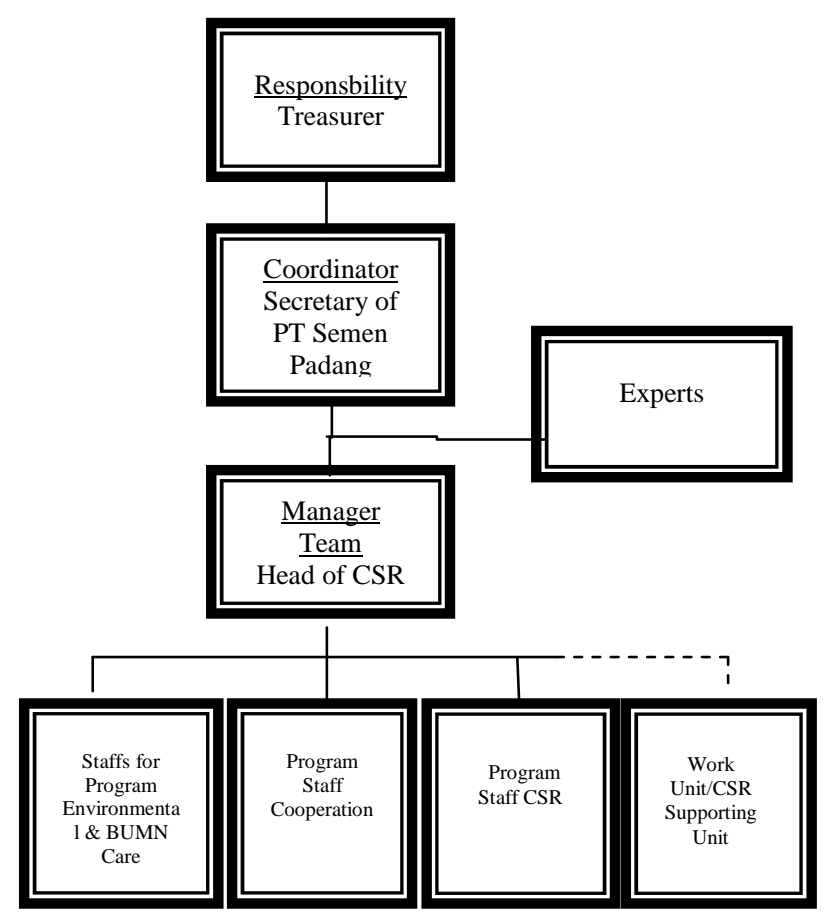

Fig. 1 Structure of organization CSR team (PT-SP, 2010)

Partnership Program (PK) could help the productive small to medium work ("UKM") in all economic sectors (such as industry, trade, agriculture, plantation, fishery, etc). Requirements needed for the "UKM" to be helped were explained in regulations stated by CSR of PT. Semen Padang [9].

Program CSR for EG and NCC was a kind of program giving a non-bound help to the people to improve the society welfare. This program included aids for disasters, either formal or informal education, improvement health facilities, development of facilities for religious activity, and for sustainable environment.

Furthermore, besides both previous programs, there was another CSR program called Non-PPEB. This program was a kind of aid aiming to support social activities in the society, such as aid for religious activities, aid for National Event celebration, etc. Then, the fund was also used for any activities planned and executed by PT Semen Padang for the society around, such as sport clubs, traditional art clubs, bazaar activities, as well as collecting and distributing people charity ("zakat"), and many other things.

Besides all above, PT Semen Padang also gave a chance for the people in the society to work at PT Semen Padang through job outsourcing, business cooperation, and local training. Then, CSR PT Semen Padang also distributed scholarships for outstanding students in pursuing their study universities.

\section{B. Allocation of CSR Budget of Company}

\section{1) General Allocation}

As a big industry in West Sumatra, PT Semen Padang has contributed to the society either local or national through the 
CSR program, besides tax allocation. Based on CSR calculation, in 2010, PT Semen Padang only needed to allocate Rp 12.94 billion (2\% of the profit) for the CSR program. However, it had paid for Rp. 17.139 billion for CSR in that year. Based on the amount of the budget it had paid, it can be concluded that PT. Semen Padang had not only fulfilled its duty (compliance to laws and regulations) but it also had done the CSR beyond the compliance.

There was an increase of CSR budget allocation from 2009 to 2012. In 2010, the CSR budget allocated increased by $20 \%$ compared to that in 2009 . The increase reached $>40 \%$ for Partnership Program (PP), almost $300 \%$ for legacy in PP, while for environmental guidance (EG) as well as for non-PPEG programs the increase was $<2 \%$. During the 5 years (2008-2012), the highest CSR budget paid by PT Semen Padang was found in 2012, which was $>300 \%$ compared to that in 2009. Of three programs introduced by PT. Semen Padang, the partnership program (PP) was allocated for the highest budget which was around 50\% (37.5-57.0\%), then followed by non-PPEG, and finally EG.

Partnership program was a form of program giving loan for people (in person) for their capital in starting or continuing the works. This fund must be returned to the Corporation (CSR of PT Semen Padang), in order to be used by other people.

As partnership program, environmental guidance program was also conducted by PT Semen Padang. This program was aimed to improve the human resource capacity, infrastructure, economy, culture, as well as religious activities of the society.

\section{2) Budget Allocation of CSR}

Based on key informant from CSR Program of PT. Semen Padang, there was no specific mechanism aimed to implement CSR Program in Batu Gadang. Globally, CSR of PT Semen Padang has set rules for the CSR program, but not detail. So, every body, or group, or organization must write proposal to gain fund, then the proposal have to be signed by local government ("RT, RW, Lurah"), before getting approval from local non-government organization ("KAN").

However, as reported by "LURAH", Batu Gadang that there is no specific rules to be followed in writing the proposal. Furthermore, PT Semen Padang did not give exact time how long they have to wait for the realization of the proposal. Based on the Batu Gadang society, generally, PT Semen Padang has not yet socialized the programs of the CSR as well as how to get them. People did not know what the difference between programs in PT Semen Padang and other loan sources is.

Based on "Lurah" in Batu Gadang, whether every proposal is approved or not, and how much fund was received by people was not reported to "Lurah". So far, there is no exact data about people or organization receiving and amount of fund got from CSR program of PT Semen Padang in Batu Gadang. Therefore, synchronization between CSR program of PT Semen Padang and other programs implemented by government is hard to conduct.

In proposing some help especially for PP, people must show the guarantee besides writing proposal. It is good in one part, because people have to work hard. On the other hand, it means that people having nothing will not get the loan from CSR program of PT Semen Padang. It was hard for them to change their life.

Among the three programs (PP, EG, Non-PPEG) implemented in Batu Gadang, partnership program was successful enough. In 2011, from total fund (Rp 260 million) allocated by CSR PT Semen Padang, 84\% (Rp. 218.4 Million) was dominated by industrial sector. It was noted that almost all of the industrial sectors in Batu Gadang were partners of PT Semen Padang. The number of this program as well as the total of the fund received by Batu Gadang society was almost the same every year since year 2011. It indicated that there was no development of the program, and there was no new programs introduced to improve society welfare in Batu Gadang.

Environmental Guidance (EG) program was divided into 2 sub programs, those were incidental and monthly program. Based on key informant, this program, as Partnership program, did also not change especially for the routine program, either the amount or the form, by time since the last 3 years since year 2011. For human resource improvement, PT Semen Padang through its CSR program gave scholarship for good students as well as for poor family students from elementary school to university. Moreover, informal training was also conducted for unschooled children and for general society. This scholarship had been distributed by PT Semen Padang far beyond the CSR Program. Process of aid distribution mechanism by CSR PT Semen Padang to Batu Gadang society in education and in culture field was the same.

Besides giving scholarship to students, PT Semen Padang had also developed schools from kindergarten to senior high school for people living around PT Semen Padang including Batu Gadang. The schools were managed by PT. Igasar, a contractor of PT Semen Padang. These schools helped people very much especially for students could not be accepted in public school. Then, the school quality was good.

Based on data in Tabel 4, it can be calculated that amount of scholarship distributed by PT Semen Padang in Batu Gadang in 2013 was $9.61 \%$ (of the total allocated with the number of students receiving was $6.23 \%$ of the total students in the area. It means that amount of scholarship allocated to students in Batu Gadang was higher than the average. This indicated that PT Semen Padang through its CSR program had given more attention especially in education to people in Batu Gadang. However, if it is compared between scholarship received and the total people in Batu Gadang, the amount of scholarship received was still far from what the society needed.

Furthermore, to improve the quality of non-student human resources, such as unschooled youg people and housewives, PT Semen Padang through its CSR program had given training for them. Among the materials trained were sewing, and cooking for housewives, electronics, machines, and workshops for unschooled young men. This training was aimed to initiate the entrepreneur feeling of people to be self-sufficient, and then to eliminate poverty in Batu Gadang, as well as around PT Semen Padang in general.

Based on data collected, in general, CSR PT Semen Padang had well implemented the fund for education. This was indicated by the total amount of fund had been 
distributed for education, either formal or informal, for outsourcing, as well as for work field initiation since year 2011. The treasurer of PT Semen Padang [10] proclaimed that it committed to improve human resources through education, because human resource was a national capital that must be optimally managed and developed. For that, PT Semen Padang reached it through EA and NCC programs in the CSR.

However, even though people in Batu Gadang had received aids for education, they were still unsatisfied. It was described in their activities as published in local daily news. From that, it was concluded that there was no cooperation between Batu Gadang society and PT Semen Padang. Batu Gadang society did not have sense of belonging yet toward the company, on the other hand, PT Semen Padang was not yet seriuous in developing them.

The misunderstanding between Batu Gadang society or people in Lubuk Kilangan in general and PT Semen Padang could be reduced if there was transparency about the CSR program between them. Therefore, people first must be educated in order to be able to accept some rules given by PT Semen Padang as long as it is fair for all. On the other hand, PT Semen Padang had to be fair and wise in deciding something for the people. This was hoped to create harmonized or good relationship between people and the firm as well as the sustainability of the firm.

Furthermore, PT Semen Padang was hoped to be able to develop a new system in implementing the CSR program within Batu Gadang society. The people in Batu Gadang and the PT Semen must sit together to discuss what kinds of problems the society have and what kinds of programs that PT Semen Padang has. What is the priority and what is the secondary could be agreed if there is a transparency and socialization. Decision started with comprehensive study and discussion and then ended with agreement will give good result. Therefore, the CSR program of PT Semen Padang could be effective and efficient.

\section{Role of "KAN", a local non-government organization, in Implementing CSR Program}

Based on "KAN" its organization must be included in implementing CSR program of the PT Semen Padang. This will help the CSR to be more effective in the implementation. If "KAN" has become a part of PT Semen Padang in implementing the CSR program, it is hopefully the misunderstanding among the people or organizations in the society can be avoided. This could be true that "KAN" knows and understands the people more than the PT Semen Padang does.

In order to increase people education in Batu Gadang, "KAN" hoped that PT Semen Padang through its CSR program can conduct (1) any training, vocational, and TOT for any local organizations such as "KAN, Karang Taruna, Bundo Kanduang", etc, therefore they can also teach other people within or out of the society. Then, for school age children, besides giving scholarship, it is suggested PT Semen Padang through the CSR program adopt the children as they own to be funded and schooled, especially for common children from poor families.

\section{Response and Expectation of Batu Gadang Society from CSR Program}

Generally, people in Batu Gadang did not know well yet what CSR is. They just said that they used to receive some aids (fund) from PT Semen Padang such as scholarship for children, free medical for manula and widows, religious activities, public facilities, as well as street development, etc. They thought that what PT Semen Padang through its CSR gave so far was a kind of "charity". Through people to people, some knew that CSR PT Semen Padang can give a loan as a capital for people to conduct their business.

Actually, based on the fact, PT Semen Padang through its CSR program has to give extra attention to Batu Gadang society due to some reasons. First, raw material of cement for the cement factory was located in Batu Gadang. It means that PT Semen Padang exploits the area of Batu Gadang for its profit. Second, area of company/firm/factory is also in Batu Gadang. Therefore, negative impact of the factory which is pollution especially in form of sound, ash, tremor, either during the exploitation of the raw material or during the processing of the cement is felt by the society. That is why most of people in Batu Gadang thought that what PT Semen Padang had done in their area was not yet balance, it was still far from what it has to be. Fundamentally, Batu Gadang has a good potency for development of agriculture, either for food crops, animal husbandry, or for fishery. However, the aids given were not yet based on the potency it has. Therefore, to be more effective and efficient, CSR allocation in Batu Gadang must be based on the potency.

\section{CONCLUSIONS}

Based on the research conducted, it can be concluded that CSR program of PT Semen Padang followed the rules stated in the government regulation and the technical implementation itself. Three (3) programs of the CSR implemented were "Partnership Program" (PP),"Environmental Guidance (EG) and National Company Care (NCC) Program, and other than both Programs (Non PP-EG). Those had been done in Batu Gadang and other areas since few years ago. Among the program, Partnership Program seemed to be better than other programs in improving society welfare, even though it still needs improvement.

Based on the fact found, it is suggested that in implementing the CSR programs, PT Semen Padang should cooperate with the local organization, such as "KAN, Karang Taruna, Randai" and any other organizations in the Batu Gadang society. The company should sit together with the society to do comprehensive study on the natural and the human resources. Then, through open dialogue and cooperation it must look for the priority, what the urgent and basic need of the society as a whole. By these, implementation of the CSR program can be more effective and meaningful.

\section{ACKNOWLEDGMENT}

We would like to thank PT Semen Padang, Lurah, KAN, and people in Batu Gadang who gave information on implementation of CSR PT Semen Padang. 


\section{REFERENCES}

[1] Surat Keputusan Menteri BUMN Republik Indonesia Nomor: KEP236/MBU/2003 tanggal 17 Juni 2003.

[2] Surat Edaran Kementrian BUMN Republik Indonesia Nomor SE433/MBU/2003 tanggal 16 September 2003 tentang Petunjuk Pelaksanaannya PKBL.

[3] Undang-Undang Republik Indonesia Nomor 40 Tahun 2007 tentang Perseroan Terbatas.

[4] H. Thamrin, I.Syafganti, and B.Rangkuti. Imple-mentation of Corporate Social Responsbility Based on Social Capital in North Sumatra. CoverAge Vol, 1(1): 77-89 (2010). (in Indonesian)

[5] F. Fukuyama. The End of History and The Last Man. The Free Press. A Division of Macmillan, Inc. New York. (2006)
[6] Inayah. Role of Social Capital in Humanity Development. Ragam J. 12 (1): 43-49 (2012). (in Indonesian)

[7] Badaruddin. Social Capital and the Development in Transmission Model as an Effort to Increase Family Welfare : Case study on rubber farmers in Rao, Pasaman Regency, West Sumatra. Research Report (2006). (in Indonesian)

[8] J. W. Creswell. Research Design Qualitave and Quantave Approaches. Thousands Oaks, London: Sage. (1994)

[9] PT. Semen Padang. Technical Guidance for Corporate Social Responsbility (CSR) PT. Semen Padang. Document No. PD/PSM/013, 1 October (2010). (in Indonesian)

[10] Sumbar Pos. Native Society Request ("Anak nagari menuntut") Sumbar Pos tanggal 11 April 2013, terbit setiap minggu di Padang. (2013) 